\title{
Complement component 3 deficiency
}

INSERM

\section{Source}

INSERM. (1999). Orphanet: an online rare disease and orphan drug data base.

Complement component 3 deficiency. ORPHA:280133

Complement component 3 deficiency is a rare, genetic, primary immunodeficiency characterized by susceptibility to infection (mainly by gram negative bacteria) due to extremely low C3 plasma levels. Patients typically present recurrent episodes of sinusitis, tonsillitis, and/or otitis, as well as upper and lower respiratory tract infections (including pneumonia) and skin infections, such as erythema multiforme. Autoimmune disease resembling systemic lupus erythematosus and mesangiocapillary or membranoproliferative glomerulonephritis may develop, resulting in renal failure. 